\title{
Ex vivo lung rehabilitation: A double-edged sword
}

\author{
Bradley LeNoir, MD, MPH, and Chadrick E. Denlinger, MD
}

From the Division of Cardiothoracic Surgery, Medical University of South Carolina, Charleston, SC.

Disclosures: Authors have nothing to disclose with regard to commercial support.

Received for publication May 25, 2018; revisions received May 25, 2018; accepted for publication May 30, 2018; available ahead of print July 6, 2018.

Address for reprints: Chadrick E. Denlinger, MD, 114 Doughty St, Suite 201, Charleston, SC 29425 (E-mail: denlinge@musc.edu).

J Thorac Cardiovasc Surg 2018;156:1316-7

$0022-5223 / \$ 36.00$

Copyright (c) 2018 Published by Elsevier Inc. on behalf of The American Association for Thoracic Surgery

https://doi.org/10.1016/j.jtcvs.2018.05.108

Despite advances in preservation and surgical techniques, the 5-year survival for lung transplant recipients remains approximately $55 \%$, with the primary cause of death after the first year remaining chronic lung allograft dysfunction. Numerous studies have demonstrated a correlation between primary graft dysfunction (PGD) at the time of transplant and chronic lung allograft dysfunction. ${ }^{1}$ Minimizing the impact of PGD thus may improve both the short-term and long-term survivals of lung transplant recipients. Donor selection is the most important component of reducing the risk for PGD. In recent years, the implementation of ex vivo lung perfusion has been used as a strategy for assessing lungs and the risks of development of PGD before transplantation. Numerous preclinical studies have assessed therapeutic interventions for lungs while they are being perfused on the ex vivo circuit.

The Toronto group has previously published extensively on therapeutic interventions, including antibiotics, ${ }^{2}$ bronchial lavage with surfactant administration, ${ }^{3}$ and virally delivered interleukin-10 (IL-10) ${ }^{4}$ during ex vivo perfusion in small and large animal models. These studies have shown encouraging results, with improved lung compliance, decreased pulmonary vascular resistance, improved oxygenation, and a reduction of inflammatory cytokines as the result of these interventions. The Toronto group's most recent publication, the article in this issue of the Journal by Oishi and colleagues, ${ }^{5}$ suggests that virally delivered IL-10 is more efficacious when administered both during ex vivo lung perfusion and in the subsequent 4 days after transplantation. This hypothesis is supported with luciferase assays, which demonstrated enhanced penetrance when delivered in ex vivo and after transplantation relative to when the luciferase vector was delivered after transplantation alone. Confirmatory studies showing the importance of the timing of delivery with the actual IL-10 lentivirus were not actually performed. $^{5}$ The current article thus once again demonstrates beneficial effects of IL-10 gene delivery but falls short of directly demonstrating that the timing of IL-10 delivery matters.

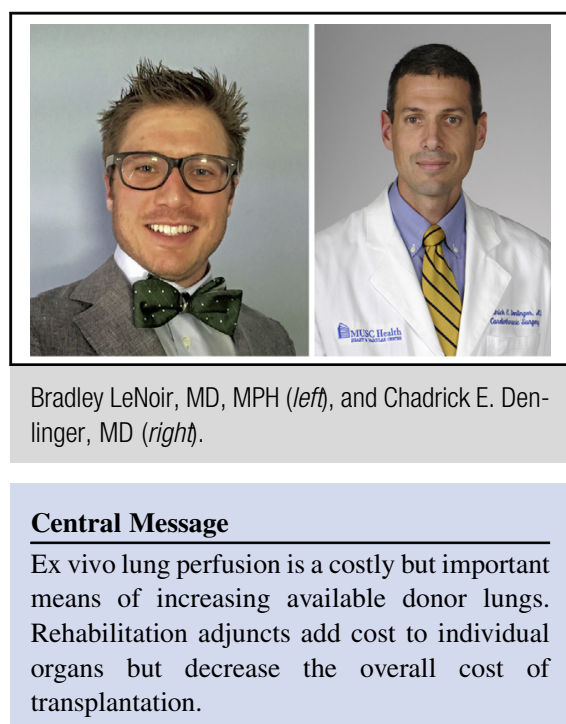

See Article page 1305 .

The cost of lung rehabilitation during ex vivo perfusion should be considered. The current costs of lung perfusate and disposable equipment are substantial, and this has diminished enthusiasm for widespread implementation. The cost of ex vivo perfusion is compounded by the less than $100 \%$ utilization rate of lungs that have been evaluated on the circuit. The addition of further interventions for lung rehabilitation during ex vivo perfusion should be viewed as a double-edged sword. Although any adjunct further increases the cost of ex vivo perfusion, adjuncts that increase the conversion of unusable organs to usable organs may actually increase the overall "return on investment" for lungs evaluated with ex vivo perfusion. Ongoing investigations of ex vivo lung perfusion adjuncts should also consider evaluating the cost of the intervention and the potential cost savings attributable to being able to utilize more organs and to decreased hospital costs for recipients with improved graft function.

\section{References}

1. Whitson BA, Prekker ME, Herrington CS, Whelan TP, Radosevich DM, Hertz MI, et al. Primary graft dysfunction and long-term pulmonary function after lung transplantation. J Heart Lung Transplant. 2007;26:1004-11.

2. Nakajima D, Cypel M, Bonato R, Machuca TN, Iskender I, Hashimoto K, et al. Ex vivo perfusion treatment of infection in human donor lungs. Am J Transplant. 2016;16:1229-37.

3. Nakajima D, Liu M, Ohsumi A, Kalaf R, Iskender I, Hsin M, et al. Lung lavage and surfactant replacement during ex vivo lung perfusion for treatment of gastric acid aspiration-induced donor lung injury. J Heart Lung Transplant. 2017;36:577-85. 
4. Machuca TN, Cypel M, Bonato R, Yeung JC, Chun YM, Juvet S, et al. Safety and efficacy of ex vivo donor lung adenoviral IL-10 gene therapy in a large animal lung transplant survival model. Hum Gene Ther. 2017;28: 757-65.
5. Oishi H, Juvet S, Martinu T, Sato M, Medin JA, Liu M, et al. A novel combined ex vivo and in vivo lentiviral interleukin-10 gene delivery strategy at the time of transplantation decreases chronic lung allograft rejection in mice. J Thorac Cardiovasc Surg. 2018;156:1305-15. 